\title{
Cytoprotective effect of tangeretin in hydrogen peroxyde-inducedoxydative stress on human umbilical vein endothelial cells (HUVECs)
}

\author{
Riris Istighfari Jenie ${ }^{1}$, Irfan Muris Setiawan ${ }^{1}$, Ikhlas Muhammad Jenie ${ }^{2}$, Haruma Anggraini \\ Muflikhasari $^{3}$ \\ ${ }^{1}$ Faculty of Pharmacy, Universitas Gadjah Mada, Yogyakarta, Indonesia \\ ${ }^{2}$ Faculty of Medicine and Health Sciences, Universitas Muhammadiyah Yogyakarta, Yogyakarta, Indonesia \\ ${ }^{3}$ Faculty of Biology, Universitas Gadjah Mada, Yogyakarta, Indonesia
}

Email: riris_jenie@ugm.ac.id

\begin{abstract}
ABSTRAK
Cekaman oksidatif diketahui merupakan pemicu terhadap kerusakan jaringan vaskuler yang kemudian mengakibatkan timbulnya penyakit hipertensi, aterosklerosis, dan gagal jantung. Senyawa polimetoksiflavon yang terkandung dalam buah sitrus seperti tangeretin dan nobiletin telah diketahui memiliki aktivitas biologik, antara lain menurunkan kadar kolesterol dan sebagai antiinflamasi. Mekanisme penting yang memperantarai aterosklerosis adalah terjadinya cekaman oksidatif, yang menyebabkan disfungsi sel endotel. Penelitian ini bertujuan untuk mengetahui efek sitoprotektif tangeretin terhadap cekaman oksidatif pada sel HUVEC yang diinduksi dengan hidrogen peroksida. Viabilitas sel ditentukan melalui metode MTT. Sel diberi perlakuan seri konsentrasi tangeretin $(12,5 ; 100$; and $200 \mu \mathrm{M})$ selama 24 jam sebelum diberi perlakuan $600 \mu \mathrm{M} \mathrm{H}_{2} \mathrm{O}_{2}$ selama 4 jam. Analisis viabilitas sel menunjukkan bahwa tangeretin pada konsentrasi rendah, 12,5 $\mu \mathrm{M}$, tangeretin menghambat sitotoksisitas yang diinduksi oleh $\mathrm{H}_{2} \mathrm{O}_{2}$ dan bahkan menginduksi proliferasi sel. Namun demikian, pada konsentrasi tinggi, tangeretin tidak mampu menghambat sitotoksisitas $\mathrm{H}_{2} \mathrm{O}_{2}$ dan justru menginduksi sitotoksisitas yang lebih tinggi daripada $\mathrm{H}_{2} \mathrm{O}_{2}$. Berdasarkan hasil ini, efek sitoprotektif tangeretin terhadap stress oksidatif memerlukan optimasi terhadap konsentrasi yang diaplikasikan.
\end{abstract}

Kata kunci: Tangeretin, cekaman oksidatif, sel endotel vena umbilical manusia (HUVEC), hidrogen peroksida.

\section{INTRODUCTION}

Reactive oxygen species (ROS) is a potent pathogenic mechanism in atherosclerosis, a major player in the initiation and progression of cardiovascular dysfunction associated with diseases such as hypertension, atherosclerosis, diabetes mellitus, and chronic heart failure (Taniyama and Griendling, 2003). Oxidative stress, defined as

\begin{abstract}
Oxydative stress is known as a major trigger in cardiovascular dysfunction that leads to hypertension, atherosclerosis, and chronic heart failure. Polymethoxyflavone such as tangeretin and nobiletin has been reported to have biological activity including reducing cholesterol level and anti inflammation activity. The critical point that mediates atherosclerosis is the formation of stress oxidative which causes endothelial cells dysfunction. This study was conducted to explore the effect of tangeretin in protecting $\mathrm{H}_{2} \mathrm{O}_{2}$-induced oxidative stress on HUVEC. Cell viability was determined by using MTT assay. Cells were treated with different concentrations of tangeretin $(12.5 ; 100$; and 200 $\mu \mathrm{M})$ for $24 \mathrm{~h}$ before exposed to $600 \mu \mathrm{M} \mathrm{H}_{2} \mathrm{O}_{2}$ for $4 \mathrm{~h}$. Cells viability analyses showed that at low concentration (12.5 $\mu \mathrm{M})$, tangeretin inhibited $\mathrm{H}_{2} \mathrm{O}_{2}$ induced cytotoxicity. Furthermore, it induced cells proliferation. However, at high concentration, it failed to protect HUVEC from $\mathrm{H}_{2} \mathrm{O}_{2}$-induced cytotoxicity and increased the cytotoxicity of $\mathrm{H}_{2} \mathrm{O}_{2}$. Based on this result, tangeretin in low concentration has a potential to reduce oxidative stress on HUVECs.
\end{abstract}

Keywords: Tangeretin, oxidative stress, human umbilical vein endothelial cells (HUVECs), hydrogen peroxide.

imbalance of pro-oxidants and antioxidants in the organism (Taniyama and Griendling, 2003). The ROS underlies redox chemistry involving reductionoxidation reactions and formation of the univalent reduction of oxygen, i.e. superoxide $\left(\mathrm{O}_{2}^{-}\right)$(Stocker and Keaney, 2004). Although superoxide itself has injury effects on vascular function, it is also play 
major in producing other reactive species by several enzyme systems (Taniyama and Griendling, 2003; Stocker and Keaney, 2004). Dismutation of superoxide by superoxide dismutase enzyme (SOD) will produce the more stable ROS, i.e. hydrogen peroxide $\left(\mathrm{H}_{2} \mathrm{O}_{2}\right)$, which is then converted enzymatically into $\mathrm{H}_{2} \mathrm{O}$ by catalase and glutathione peroxidase (GPx) (Taniyama and Griendling, 2003). Under normal circumstances the levels of ROS are low enough to be removed by the natural defense systems in the body. Several antioxidant enzymes in the cells may convert the stable-ROS into nonreactive form. Therefore, it inhibits the formation of more reactive ROS (Stocker and Keaney, 2004). Thus, homeostasis between production of ROS andantioxidant plays major role in the prevention of oxidative stress.

Oxidative stress is one of potent pathogenic mechanism in atherosclerosis (Hansson, 2005) by stimulating cellular injury, mitochondrial dysfunction, and apoptosis (Madamanchi and Runge, 2007). One possible mechanism by which oxidative stress may trigger cellular toxicity in cell is by inducting the release of cytochrome $c$ into the cytosol, which in turn triggers the mitochondria apoptotic pathway (Wen et al., 2013). Atherosclerosis is a chronic inflammatory response to high serum cholesterol levels, leading to plaque formation and the hardening of arteries. Cumulatively, these effects increase an individual risk of stroke, myocardial infarction or additional systemic complications (Singhet al., 2002). The progressive nature of this disease can remain undetected for many years (Hansson, 2005). Atherosclerosis induce endothelial dysfunction, that functions as an impermeable barrier whose integrity plays important roles in prohibiting leukocyte adhesion, reducing inflammation, and supporting the vasculature that release paracrine signaling peptides to regulate vascular tone during hemodynamic stress and oxidative stress (Davidson and Duchen, 2007). Therefore, it is need to develop new compound affecting multiple target like oxidative stress and mitochondria may afford better protection against atherosclerosis.
In natural source, flavonoids have been known as a potent antioxidant. Epidemiological studies have reported that diets rich in fruits, vegetables, and tea might reduce risk of chronic diseases such as cancer and cardiovascular diseases (Mulvihiland Huff, 2012). Polymethoxyflavones (PMF) compounds in orange peel are one kind of flavonoids that was reported to have the ability in lowering-cholesterol levels (Kurowska et al., 2004). Previous report showed that water extract of sweet orange peel inhibited the cytotoxic effect of tBHP on HepG2 cells. The phenolic bioactive compounds in the extract, including tangeretin (Fig.1), may responsible on that effect (Chen et al., 2012).

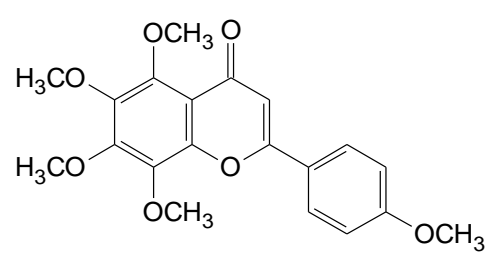

Figure 1. The molecule structure of tangeretin

To investigate whether tangeretin protected endothelial cells from oxidative stress, we used hydrogen peroxide $\left(\mathrm{H}_{2} \mathrm{O}_{2}\right)$ to induce oxidative stress in human umbilical vein endothelial cells (HUVECs). In previous study (Wen et al., 2013), treatment with $\mathrm{H}_{2} \mathrm{O}_{2}$ in endothelial cell culture was reported to stimulate ROS concentration, decrease antioxidant enzymes, increase mitochondrial dis-function, and increase product of lipid peroxidation enzyme.

This study elucidates the potency of tangeretin to protect endothelial cells against oxidative stress and endothelial dis-function. Thus, it is potential to be developed to prevent atherosclerosis.

\section{MATERIALS AND METHOD}

\section{Isolation and Cell culture}

Human umbilical vein cells (HUVECs) are isolated from the vein of the umbilical cord by 1 $\mathrm{mg} / \mathrm{mL}$ collagenase (kindly given by Prof. Hiroshi Itoh) treatment (Ethical clearance from Medical and 
Health Research Ethics Committee (MHREC) Faculty of Medicine Universitas Gadjah Mada - Dr. Sardjito General Hospital No. KE/FK/619/EC). Cells seeded on gelatin coated dish and cultured in monolayers at $37^{\circ} \mathrm{C}$ in a $5 \% \mathrm{CO}_{2}$ atmosphere in Dulbecco modified Eagles medium (DMEM low glucose) (Gibco) supplemented with $10 \%$ heat inactivated $10 \%$ fetal bovine serum (FBS) (Sigma); $1 \%$ penicillin/streptomycin (Sigma); 0.5\% fungizon (Gibco); $1 \mathrm{ng} / \mathrm{mL}$ vascular endothelial growth factor (VEGF) (Sigma); and $30 \mu \mathrm{g} / \mathrm{mL}$ endothelial cell growth factor (ECGF) (Sigma).

\section{Cytotoxicity assay}

Cell viability was measured by the MTT assay (Sigma), which measures the mitochondrial reduction MTT to formazan. HUVECs, $70-80 \%$ confluence, in 96-well plates were cultured in 10\% FBS-DMEM containing $1 \%$ pen-strep at $37^{\circ} \mathrm{C}$ in $5 \%$ $\mathrm{CO}_{2}$ atmosphere for $24 \mathrm{~h}$. Cells were treated a series of concentrations of tangeretin (Sigma) (12.5; 100; and $200 \mu \mathrm{M}$ ) for $24 \mathrm{~h}$ before exposed to $600 \mu \mathrm{M} \mathrm{H}_{2} \mathrm{O}_{2}$ (Merck) for $4 \mathrm{~h}$. Following $\mathrm{H}_{2} \mathrm{O}_{2}$ treatment, $0.5 \mathrm{mg} / \mathrm{mL}$ MTT was added to each well and cultures were incubated for $4 \mathrm{~h}$ at $37^{\circ} \mathrm{C}$. The dark blue formazan crystals formed in intact cells were solved in $10 \%$ sodium dodecyl sulfate (SDS). The purple colour of the solution was measured by ELISA reader (BioRad) $\lambda 550 \mathrm{~nm}$ and analyzed. Cell viability was calculated as bellows:

Cell viability $(\%)=$ (absorbance of each treated group: absorbance of control) $\times 100 \%$.

\section{RESULTS AND DISCUSSION}

The bioactive compounds contained in orange peel have been suggested to contribute in the effect of water extract of sweet orange peel in protecting HepG2 cells from oxidative stress induced by t-BHP (Chen et al., 2012). Tangeretin, together with nobiletin, is one of the polymethoxylated flavones that are abundant in the orange peel. This study explored the potency of tangeretin in protecting endothelial cells from oxidative stress by measuring cells viability using MTT.

We determined the effect of tangeretin in protecting endothelial cells by pre-treated the cells with different concentrations of tangeretin $(12.5$; 100 ; and $200 \mu \mathrm{M}$ ) for $24 \mathrm{~h}$, before exposing it to $600 \mu \mathrm{M}$ $\mathrm{H}_{2} \mathrm{O}_{2}$ for $4 \mathrm{~h}$. As shown in Fig.2, treatment of $\mathrm{H}_{2} \mathrm{O}_{2}$ alone reduced cells viability much smaller than control cells. On the contrary, cells pre-treated with $12.5 \mu \mathrm{M}$ tangeretin were not affected by $\mathrm{H}_{2} \mathrm{O}_{2}$ treatment and grow higher than control cells. However, high concentration of tangeretin, 100 and $200 \mu \mathrm{M}$, were failed to protect the cells from $\mathrm{H}_{2} \mathrm{O}_{2}$ treatment. These results showed that $\mathrm{H}_{2} \mathrm{O}_{2}(600 \mu \mathrm{M})$ was cytotoxic on HUVECs, and tangeretin had different effect depending on its concentration. Pretreatment with low concentration of tangeretin preserved endothelial cell viability, but high concentration of tangeretin did not.

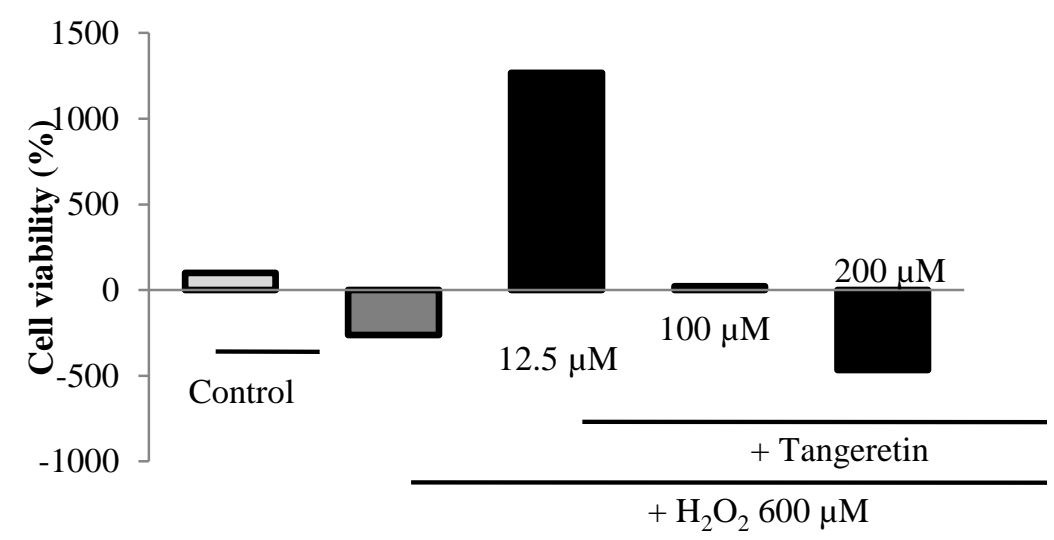

Figure 2. Profile the effect of tangeretinon Human umbilical vein endothelial cells (HUVECs) against hydrogen peroxide $\left(\mathrm{H}_{2} \mathrm{O} 2\right)$ treatment. HUVECs were treated with different concentrations of tangeretin (12.5; 100; and $200 \mu \mathrm{M}$ ) for $24 \mathrm{~h}$, then exposed to $600 \mu \mathrm{M} \mathrm{H}_{2} \mathrm{O}_{2}$ for $4 \mathrm{~h}$. Following $\mathrm{H}_{2} \mathrm{O}_{2}$ treatment, the viability of the cells were then measured using MTT solution and as described in the method. 
Moreover, low concentration tangeretin may have a proliferative effect for the endothelial cells because at this concentration, cells viability were higher than control, although it has been exposed tocytotoxic agent, $\mathrm{H}_{2} \mathrm{O}_{2}$. From the present result (Fig.2), it is suggested that low concentration of tangeretin may protect cells from cytotoxicity caused by oxidative stress. However, high concentration induced cytotoxicity. The potential of tangeretin in reducing oxidative stress may involve several mechanisms such as reducing ROS and lipid peroxidation products, and increasing catalase enzyme activities. Tangeretin was reported to limit endogenous ROS production but it did not scavenge DPPH radical (Yoon et al., 2011). Wen et al. (2013) showed that $\mathrm{H}_{2} \mathrm{~S}$ inhibited $\mathrm{H}_{2} \mathrm{O}_{2}$ mediated mitochondrial dysfunction in human endothelial cells by preserving antioxidant defenses.

Therefore, it is important to further examine the antioxidant system and mitochondrial integrity, including analysis of ROS and lipid peroxidation products; endogen antioxidant enzyme activities; and expression of cytochrome c. This paper demonstrates the potential of tangeretin as a cytoprotective agent.

\section{CONCLUSION}

In conclusion, tangeretin in low concentration has a potential to reduce oxidative stress on HUVECs. However, high concentration of tangeretin cause cytotoxicity, therefore further experiments are needed to optimize its concentration as cytoprotective.

\section{ACKNOWLEDGEMENT}

1. Balitbangkes Kemenkes $\mathrm{RI}$ for the research grant from its program, RISBIN IPTEKDOK 2014.

2. Dokter Dwi Haryadi Sp.OG, for the umbilical cord samples.

3. Prof. Hiroshi Itoh from Nara Institute Science and Technology (NAIST) Japan for the collagenase.

\section{REFERENCES}

Taniyama, Y. and Griendling, K.K. 2003. Reactive oxygen species in the vasculature: molecular and cellular mechanism. Hypertension 42: 1075-81.

Stocker, R. and Keaney, J.F. Jr. 2004. Role of oxidative modifications in Atherosclerosis. Physiol Rev.84: 1381-1478.

Hansson, G.K. 2005. Mechanisms of disease: Inflammation, atherosclerosis, and coronary artery disease. $N$ Engl J Med.352: 1685$1695+1626$

Singh R.B., Mengi S.A., Xu Y-J, Arneja A.S., and Dhalla N.S. 2002. Pathogenesis of atherosclerosis-A multifactorial process. ExpClinCardiol. 7: 40-53.

Madamanchi, N.R. and Runge, M.S. 2007. Mitochondrial Dysfunction in Atherosclerosis. Circ Res.100: 460-473.

Wen, Y.D., Wang, H., Kho, S.H., Rinkiko, S., Sheng, X., Shen, H.M., and Zhu, Y.Z. 2013. Hydrogen Sulfide Protects HUVECs against Hydrogen Peroxide Induced Mitochondrial Dysfunction and Oxidative Stress. PLoS One 8:e53147.

Davidson, S.M. and Duchen, MR. 2007. Endothelial mitochondria: Contributing to vascular function and disease. Circ Res.100: 11281141.

Mulvihil, E.E. and Huff, M.W. 2012. Protection from metabolic dysregulation, obesity, and atherosclerosis by citrus flavonoids: activation of hepatic PGC1 $\alpha$-mediated fatty acid oxidation. PPAR Research. 857142.

Kurowska, E.M., Manthey, J.A., Casaschi, A., and Theriault A.G. 2004. Modulation of HepG2 Cell Net Apolipoprotein B Secretion by the Citrus Polymethoxyflavone, Tangeretin. Lipids 39:143-151.

Yoon J.H., Lim T.G., Lee K.M., Jeon A.J., Kim S.Y., and Lee K.W. 2011. Tangeretin Reduces Ultraviolet B (UVB)-Induced Cyclooxygenase2 Expression in Mouse Epidermal Cells by Blocking Mitogen-Activated Protein Kinase (MAPK) Activation and Reactive Oxygen Species (ROS) Generation. J Agric Food Chem.59:222.

Chen, Z.T., Chu, H.L., Chyau, C.C., Chu, C.C., and Duh, P.D.2012. Protective effects of sweet orange (Citrus sinensis) peel and their bioactive compounds on oxidative stress. Food Chem.135:2119. 